\title{
Brabant in verzet tegen Alva's tiende en twintigste penning*
}

\author{
G. JANSSENS
}

Weinige perioden uit onze geschiedenis kenden een zo grote belangstelling vanwege de historici als de Opstand tegen Spanje. Toch loont het telkens weer de moeite één of andere episode uit dat tijdvak aan een nieuw onderzoek te onderwerpen. Vooral de periode van Alva's gouverneurschap in de Nederlanden heeft behoefte aan een nieuwe aanpak. Wie Alva zegt, denkt ook onmiddellijk aan de tiende en twintigste penning. Naast de legering van troepen en de oprichting van de 'Raad van Beroerten' verwekten ook deze nieuwe belastingen heel wat wrevel en tegenstand.

Vooral H. A. Enno van Gelder en J. Craeybeckx onderscheidden zich bij de behandeling van Alva's nieuwe belastingen ${ }^{1}$. Waar H. A. Enno van Gelder in de actie tegen de tiende en twintigste penning niet veel 'principieel' verzet ziet en de hele zaak eerder als 'een hand-op-de-beurs politiek van het ergste soort' afschildert, toont J. Craeybeckx aan dat er nog wel wat meer was. Hij zoekt naar een verklaring voor een zo stevige oppositie, te meer daar bewezen is dat de tiende en twintigste penning nooit werden geïnd. Deze belastingen kunnen bijgevolg niet verantwoordelijk zijn voor de economische depressie van de tweede helft der zestiende eeuw. Craeybeckx relativeert sterk het aandeel van de clerus in het verzet. Hij stelt de kooplieden en ambachtslui in het gelijk die om economische redenen de nieuwe belastingen verwierpen. De tiende penning was volgens hem een buitensporig hoge belasting, een zienswijze die bij Enno van Gelder niet zo veel gewicht krijgt.

Onze aandacht gaat dus ook uit naar de zo beruchte tiende en twintigste penning.

* Lijst van afkortingen van geraadpleegde archiefstukken: ARAB, Pap. St. Aud.: Algemeen Rijksarchief Brussel, Papieren van Staat en Audiëntie; ARAB, Man. Div.: Algemeen Rijksarchief Brussel, Manuscrits Divers-Handschriftenverzameling; BM, Add.: British Museum London, Additional Manuscript; GAsH: Gemeentearchief's-Hertogenbosch; RAA, GAM: Rijksarchief Antwerpen, Gemeentearchief van Mechelen; SAA, Pk.: Stadsarchief Antwerpen, Privilegiekamer; SAB: Stadsarchief Brussel; SAL: Stadsarchief Leuven.

1. H. A. Enno van Gelder, 'De tiende penning', Tijdschrift voor geschiedenis, XLVIII(1933) 1-36, 120-144; J. Craeybeckx, 'Alva's tiende penning een mythe?', Bijdragen en mededelingen van het Historisch Genootschap, LXXVI (1962) 10-42. Veel van professor Craeybeckx' bevindingen bleven nog ongepubliceerd in zijn onuitgegeven licentiaatsverhandeling 'De tiende penning van Alva in Vlaanderen en Brabant' (Gent, 1946). Prof. Craeybeckx was zo vriendelijk ons zijn verhandeling ter inzage te geven. Wij willen hem dan ook speciaal onze oprechte dank betuigen. Een nieuwe benadering van Alva, tevens bedoeld als status quaestionis van het onderzoek, brengt M. Dierickx, 'Nieuwe gegevens over het bestuur van de hertog van Alva in de Nederlanden', Bijdragen tot de geschiedenis der Nederlanden, XVIII (1963-64) 167-192. 
Vele aspecten van het verzet tegen deze belastingen bleven immers nog steeds in het duister. Wij willen speciaal het Brabantse verzet onder de loupe nemen. Zo stelden we ons de vraag naar de motieven die dit verzet dreven, naar de leiders, naar de wijze van onderhandelen met de landvoogd.

Vermits het toestaan der beden via de provinciale Statencolleges geregeld werd, zullen wij onze aandacht vooral richten op de politieke activiteit van de Staten van Brabant. In de schoot van hun vergadering kwamen de verschillende belangengroepen aan bod.

\section{EERSTE REACTIES OP HET BELASTINGPROJECT}

Don Fernando Alvarez de Toledo, hertog van Alva, stond bij zijn aankomst in de Nederlanden voor een zware financiële erfenis: de staatskas was leeg, het koninklijk domein was fl. 60.000. - boven zijn waarde belast, de staatsschuld was enorm en de negenjarige bede van 1558 liep ten einde ${ }^{2}$. Terzelfdertijd vergde de aanwezige troepenmacht een grote financiële inspanning. Om dit te verhelpen en om de Nederlanden in staat te stellen zelf de militaire lasten te dragen, kwam de hertog op 20 en 21 maart 1569 met zijn project voor de dag: een honderdste penning (1\%) op alle bezitingen, éénmaal te heffen; een twintigste penning (5\%) op de verkoop van alle onroerende goederen, ten laste van de verkoper, en tenslotte een tiende penning $(10 \%)$ op de verkoop van alle roerende goederen, eveneens ten laste van de verkoper. Tegelijkertijd zou een tiende penning geheven worden op de goederen bestemd voor de export. De tiende en twintigste penning waren als permanente belastingen bedoeld. Uitdrukkelijk werd ook gezegd dat deze hervormingen de Nederlanden zouden moeten kunnen toelaten de Spaanse oorlogsinspanningen in onze streken te financieren ${ }^{3}$.

$\mathrm{Na}$ het voorstel trokken de verschillende Statenvergaderingen zich als naar gewoonte terug om te beraadslagen. Het Brabantse antwoord liet niet lang op zich wachten. Op 4 april reeds werd de honderdste penning door de prelaten en de edelen aanvaard. De tiende en twintigste penning stonden zij toe voor een termijn van negen jaar. Toch voegden zij bij dit akkoord verscheidene kritische bemerkingen ${ }^{4}$. Alva reageerde verontwaardigd, hij eiste een onvoorwaardelijke toezegging 5 . Hieraan gevolg gevend stelden de prelaten en de edelen dezelfde dag nog een remonstrantie op en willigden zij Alva's eis in ${ }^{6}$. Het verdere verloop lag nu nagenoeg

2. Ibidem, 181. Over de negenjarige bede K. Verhofstad, De regering der Nederlanden in de jaren 1555-1559 (Nijmegen, 1937) 115-175.

3. J. Craeybeckx, 'Aperçu sur l'histoire des impôts en Flandre et en Brabant au cours du XVIe siècle', Revue du Nord, XXIX (1947) 98-99.

4. Antwerpse deputatie aan Antwerps stadsbestuur, Brussel, 5 april 1569 (n.s.), SAA, Pk., no3296.

5. Relaas, 6 en 7 april 1569 (n.s.), ibidem, no 2478, los stuk.

6. Opinie van prelaten en edelen, 7 april 1569 (n.s.), SAL. no 1703, los stuk; remonstrantie, 6 april 1569 (n.s.), SAA, Pk., no 2478, los stuk. 


\section{G. JANSSENS}

volledig in de handen van de steden, het derde lid van de Staten ${ }^{7}$. De stedelijke gedeputeerden van Antwerpen, Brussel, Leuven en 's-Hertogenbosch dienden hun stadsbestuur te raadplegen. Pas na unanimiteit binnen de stadsbesturen, tussen de steden onderling en tussen de steden en de eerste twee standen kon een voorstel door de Staten aanvaard worden. Dit was het princiep. In feite beschikte de vorst over de mogelijkheid om een weigerende minderheid te 'vervangen' en zo het verzet te breken ${ }^{8}$. Het unanimiteitsbeginsel was zeer zeker een macht, vooral dan voor de steden, maar tegelijk ook de oorzaak van het dikwijls eindeloos lang aanslepen der onderhandelingen. Niet zonder reden noemde Alva de steden de lastigste tak der Staten ${ }^{9}$.

Op 28 april verklaarde het Antwerpse stadsbestuur zich met de zienswijze der prelaten en edelen akkoord; wel maakte het zijn instemming afhankelijk van een gebeurlijke akkoordverklaring der drie andere Brabantse hoofdsteden ${ }^{10}$. Dit akkoord kan ons verwonderen, vooral wanneer we weten dat er in het stadsbestuur blijkbaar toch niet zo een eensgezindheid hieromtrent bestond ${ }^{11}$. We zien echter dat de stad aan het unanimiteitsbeginsel vasthield. Wellicht is de Antwerpse goedkeuring niet zo zeer principieel dan wel politiek-strategisch te verklaren, of was het een kompromis-oplossing tussen de magistraat en de zich verzettende ambachten?

De resterende steden kregen van de kanselier van Brabant de raad zich bij de opinie van Antwerpen aan te sluiten. Ook de hertog spoorde hen uitdrukkelijk daartoe aan ${ }^{12}$. Toch had dit maar matig succes: 's-Hertogenbosch stemde toe, Brussel en Leuven bleven weigeren ${ }^{13}$. Over de honderdste penning werden daarentegen weinig moeilijkheden gemaakt ${ }^{14}$.

Bijna drie maanden waren nu verlopen en Alva had nog geen resultaat bereikt.

7. Craeybeckx, 'Aperçu sur 1'histoire', 100.

8. L. Wils, 'De werking van de Staten van Brabant, omstreeks 1550-1650, volgens Leuvense archiefbronnen', Standen en Landen, V (1953) 4-5, 8-9.

9. Alva aan kardinaal de Espinosa, 29 april 1569, BM, Add., no 28. 386, fo 206. De steden waren samengesteld uit 'leden'. Voor Leuven hebben we de magistraat, de geslachten (= de patriciërs), de dekens van de gilde der drapperije en tenslotte de ambachten. Brussel had drie leden: de magistraat, de brede raad (= oudmagistraten plus de dekens van de gilde der drapperije) en de naties (= dekens der ambachten). Te Antwerpen: de magistraat, de raad (= oud-schepenen) en de ambachten. Een zelfde samenstelling kende het stadsbestuur van 's-Hertogenbosch.

10. Antwerpen, 28 april 1569, SAA, Pk., no 2478, los stuk.

11. R. van Roosbroeck, ed., De kroniek van Godevaert van Haecht over de troebelen van 1565 tot 1574 te Antwerpen en elders. Uitgaven van het genootschap voor Antwerpse geschiedenis (2 dln; Antwerpen, 1929-1930), II 87; J. -P van Dieren, ed., Chronycke van Antwerpen sedert het jaar 1500 tot 1575 (Antwerpen, 1843) 202.

12. Relaas, 11 mei 1569, SAA, Pk., no 480, los stuk.

13. Opinie van 's-Hertogenbosch, ongedateerd stuk, opgesteld tussen 14 en 21 mei 1569, GAsH, A. 247, fo 261-263; 12 juni 1569, SAL, no 300, fo 105; Antwerpse deputatie aan Antwerps stadsbestuur, Brussel, 15 juni 1569, SAA, Pk. no 2396.

14. J. Craeybeckx, 'La portee fiscale et politique du 100e denier du duc d'Albe', Acta Historica Bruxellensia. Travaux de 1'institut d'histoire de l'université libre de Bruxelles, I (Brussel, 1967) 348-350. 
Eén troost had hij: de koning steunde zijn politiek volledig ${ }^{15}$. De hertog zou het nu over een andere boeg gooien. Hij trachtte de Staten er van te overtuigen dat men een partiële toestemming als een goedkeuring diende te beschouwen. Hier trad hij in het voetspoor van Karel V. Na de Gentse opstand had deze immmers op 30 april 1540 de 'vervanging' voor Vlaanderen gelegaliseerd ${ }^{16}$. Alva deed ook zijn best om de Brabanders gerust te stellen: hij gaf duidelijk te verstaan helemaal niet de ondergang van de handel te beogen ${ }^{17}$. Toch lieten de ambachten in de steden zich niet overtuigen ${ }^{18}$ en dit was voor de hertog wellicht de aanleiding om zelf op te treden.

Op 13 augustus liet Alva weten 'datmen enighe leden gebreckelyck zoude vervanghen ende dat tconsent om tgebreck van het derde leth van Loeven ende tderde leth van Bruessel nyet en behoirt achter te blyven'. Hij gaf Brussel en Leuven nog veertien dagen de tijd om zich bij het akkoord aan te sluiten ${ }^{19}$. Dit gebeurde ook, respectievelijk op 19 en 22 augustus $^{20}$. De overeenkomst werd op 31 augustus officieel door Alva bekrachtigd ${ }^{21}$. Hij had een belangrijke overwinning geboekt. Tegen de traditie en de wil der Staten in had hij een niet unaniem aanvaard voorstel kunnen laten ondertekenen. Werkelijk, Alva spande zich tot het uiterste in om de macht der Staten te breken ${ }^{22}$.

\section{GEVEN EN NEMEN}

Na de in augustus 1569 afgedwongen overeenkomst leken voor Alva de moeilijkheden definitief van de baan. Toch waren de klachten en remonstranties van de steden niet ongegrond gebleken. De hertog was bezorgd voor de sociaal-economische welvaart der Nederlanden en stilaan geraakte Alva ervan overtuigd dat de tiende penning in haar oorspronkeüjke vorm té ongedifferentieerd was om aan

15. Philips II aan Alva, Madrid, 15 mei 1569 in: L. -P. Gachard, ed., Correspondance de Philippe II sur les affaires des Pays-Bas, II (Brussel, 1851) 92.

16. L. -P. Gachard, ed., Relation des troubles de Gand sous Charles Quint, par un anonyme (Brussel, 1846) 131; Enno van Gelder, 'Tiende penning', 131; J. Craeybeckx, 'De staten van Vlaanderen en de gewestelijke financiën in de XVI eeuw. Het verzet tegen Alva's tiende penning', Handelingen van de maatschappij voor geschiedenis en oudheidkunde te Gent, nieuwe reeks, IV (1950) 82.

17. L. -P. Gachard, ed., 'Relation du voyage des députés envoyés à Philippe II en Espagne, par les états de Brabant, pour réclamer contre le dixième et Ie vingtième denier: 8 mars - 11 août 1572', Bulletin de la commission royale d'histoire, 2e reeks, XI (1858) 312.

18. Opinie van Antwerpen in ibidem, 313; opinie van Brussel: Brussel, 6 en 8 augustus 1569, SAL, no 1788, los stuk; opinie van Leuven: 28 juli 1569, ibidem.

19. Antwerpse deputatie aan Antwerps stadsbestuur, Brussel, 13 augustus 1569, SAA, Pk., no 2396 , twee brieven.

20. 19 augustus $1569, \mathrm{SAB}$, no 1724 , fo $144 ; 22$ augustus 1569 , SAL, no 1789 , los stuk.

21. 31 augustus 1569, ARAB, Pap. St. Aud , no 611, fo 26-51 vo

22. G. -B. Guicciardini aan Fr. de Medici, Brussel, 25 juli 1569 in: M. Battistini, ed., 'Lettere di Giovan Battista Guicciardini a Cosimo e Francesco de' Medici scritte dal Belgio dal 1559 al 1577', Bibliothèque de l'institut historique belge de Rome, II (Rome-Brussel, 1949) 341. 


\section{G. JANSSENS}

handel en nijverheid geen schade te berokkenen. Deze reële moeilijkheid, zou hem er toe brengen met een nieuw belastingvoorstel de eigenlijke heffing van de tiende en twintigste penning uit te stellen ${ }^{23}$.

In dit perspectief stelde de hertog op 21 oktober aan de Staten van Brabant een jaarlijkse quote van fl. 542.000. - voor, als aandeel in een bede van fl. 2.000.000.- , en dit voor de tijd van zes jaar. Ook werd een tweede honderdste penning voorgesteld, deze zou na die zes jaar geïnd worden ${ }^{24}$. De Staten namen opgelucht kennis van de opschorting van de tiende en twintigste penning en gingen akkoord met de quote. In de vergadering rezen echter meningsverschillen over de wijze waarop men de gelden zou bijeenbrengen. De prelaten en de edelen stelden een belasting op een aantal (verbruiks-) goederen en diensten voor. Antwerpen wees dit verontwaardigd van de hand ${ }^{25}$. Uit de discussie komt vooral naar voren dat de prelaten, de edelen en de eerste leden van de steden (= de magistraat) gemeenschappelijke belangen hadden. Zij vermeden zorgvuldig elke kapitaal- en inkomstenbelasting. De andere leden verzetten zich krachtdadig tegen 'generale middelen' die bijna uitsluitend uit verbruiksbelastingen bestonden ${ }^{26}$. Men zat duidelijk in het slop.

De Staten hadden echter te vroeg gejuicht: de hertog had de penningen wel uitgesteld, maar niet afgeschreven. Hij zocht integendeel naar de meest geschikte middelen om zijn oorspronkelijk plan beter aanvaardbaar te maken ${ }^{27}$. Wellicht trachtte hij enkel tijd te winnen.

De eindeloze palavers der Staten bleven voor Alva een voortdurende bron van ergernis. Hij zou hun nu eens het mes op de keel zetten. Op 17 maart 1570 kreeg Brabant een gemodereerde tiende en twintigste penning voorgelegd. Het voorstel bestond uit zes punten: a. vrijgesteld van de tiende penning werden alle eerste verkopingen die in het land plaats vonden; $b$. en alle verdere verkopingen, behalve de laatste verkoop, als het verbruiksgoederen betrof; c. en alle onafgewerkte proproducten; $d$. de tiende penning diende betaald te worden op alle uit de Nederlanden uitgevoerde inlandse produkten; e., de twintigste penning werd geheven op elke verkoop van onroerend goed; f. er werd een tweede honderdste penning ingevoerd. Deze moderatie zou voor zes jaar gelden ${ }^{28}$. Alva wilde hier wellicht de ambachtslieden der steden ter wille zijn. Waren zij ook niet een van de meest opposante groepen? De prelaten en de edelen wezen het voorstel echter van de

23. Cf. Alva's brieven aan de koninklijke secretaris G. de Zayas, Antwerpen en Brussel, 12 en 31 oktober 1569 in: Colección de documentos ineditos para la historia de España, XXXVIII (Madrid, 1861) 186-188, 213-214.

24. 21 oktober 1569, SAA, Pk., no 2478, los stuk. Uitgebreid verslag over deze statenzitting: Antwerpse deputatie aan Antwerps stadsbestuur, Brussel, 21 oktober 1569, ibidem, no 2397.

25. Ibidem, no 2376, hoofdstuk tiende en twintigste penning, fo 13.

26. Ongedateerd (na 21 oktober 1569), GAsH, A. 247, fo 190-213.

27. Craeybeckx, 'Aperçu sur l'histoire', 101 en idem, 'De staten van Vlaanderen', 107-108.

28. Brussel, 17 maart 1570 (n.s.), ARAB, Pap. St. Aud., no 613, fo 33-41. 
hand $^{29}$. Komt hier nogmaals de standentegenstelling aan het licht? Alva was woedend. Zijn voorstel bereikte nu niet eens de stedelijke vertegenwoordigers! Onmiddellijk ontbood hij de gedeputeerden van de vier Brabantse steden. Hij bracht hen op de hoogte van zijn voorstel en voegde er aan toe dat de eerste twee standen deze moderatie verworpen hadden en dat hij zich daarom genoodzaakt zou zien vanaf 3 april een ongemodereerde tiende en twintigste penning in te voeren $^{30}$.

Deze mededeling sloeg in als een bom. Vooral te Antwerpen was er paniek. Liever nog wilde men de voorgestelde moderatie aannemen dan het slachtoffer worden van ongemodereerde tiende en twintigste penningen ${ }^{31}$ ! Alva's strategie bleek doeltreffend. Toch lieten Leuven en Brussel zich niet van de wijs brengen. Zij lieten weten dat ze er op stonden dat de prelaten en de edelen zelf hun opinie zouden mededelen ${ }^{32}$.

De tiende penning hing meer dan ooit als een zwaard van Damocles boven de Staten. De Statenvergadering voelde nu ook dat het hoog tijd was om in actie te komen. Op 2 april vroegen de stedelijke afgevaardigden de eerste standen te willen onderzoeken hoe men de dreigende belastingen zou kunnen afweren. Tevens verwezen ze naar het voorstel om gedurende zes jaar elk jaar f1. 542.000.— op te brengen. Na een korte discussie werd een akkoord bereikt; om erger te voorkomen verklaarden de eerste twee standen zich akkoord met het voorstel van 17 maart $^{33}$. Het woord was nu weer aan de steden. Te 's-Hertogenbosch verklaarden de eerste twee leden zich akkoord met de moderatie, toch hadden ze ook nog enkele kritische opmerkingen. Het derde lid (de dekens van de ambachten) vroeg eerst en vooral de opheffing van het militair garnizoen ${ }^{34}$. Te Leuven spraken vier leden zich uit tegen de moderatie $\mathrm{e}^{35}$. Antwerpen ging wel akkoord, maar had toch nog heel wat kritiek ${ }^{36}$. Te Brussel ging enkel het eerste lid akkoord ${ }^{37}$. Dit wat de stemming rond de moderatie betreft.

Alva bracht nu ook weer zijn voorstel betreffende de jaarlijkse quote van

29. Ongedateerd, GAsH, A. 247, fo 1-9, 388-402.

30. Brussel, 25 maart 1570 (n.s.), ARAB, Pap. St. Aud., no 613, fo 49-50 vo.

31. Antwerpen, 29 maart 1570, SAA, Pk., no 2478.

32. 30 maart 1570 , SAB, no 1724 , fo $152-152$ vo en 1 april 1570 , SAL, no 300 , fo 214 vo. De opinie van 's-Hertogenbosch hebben wij niet teruggevonden.

33. 2 april 1570 , GAsH, A. 247 , fo 6 .

34. 28 april 1570 , ibidem, fo 291-295.

35. 31 mei 1570, SAL, no 300, fo 231.

36. Antwerpen, 1 juni 1570, SAA, Pk., no 2478, los stuk en minuut van remonstranties, 20 juni 1570, ibidem, los stuk.

37. Antwerpse deputatie aan Antwerps stadsbestuur, Brussel, 23 juni 1570, ibidem, no 2396. Later conformeerde het tweede lid zich eveneens, opinie van Brussel, ongedateerd, GAsH, A. 247, fo37. 


\section{G. JANSSENS}

fl. 542.000.- te berde ${ }^{38}$. De prelaten en de edelen maakten geen noemenswaardige moeilijkheden ${ }^{39}$. In de steden werd geen unanimiteit bereikt ${ }^{40}$.

De hertog liet de Brabanders onder elkaar ruzie maken en zette zijn wil door. Op 2 augustus liet hij een belangrijk plakkaat verschijnen: de quote van fl. 542.000.werd ingevoerd en tegelijk vinden we er ook het moderatie-voorstel van 17 maart in terug ${ }^{41}$. De regeling werd door de Staten anvaard en op 13 augustus ondertekend $^{42}$. In de schoot van de Statenvergadering begonnen nu opnieuw de moeilijkheden rond het bijeenbrengen der fl. 542.000. ${ }^{43}$. Antwerpen stelde daarop voor, de nieuwe belastingen nog met één jaar uit te stellen. Men zou ondertussen kunnen zien hoe de andere gewesten hun quote opbrachten. De prelaten en de edelen verwierpen dit plan: het zou funest zijn voor de staatsinkomsten. Zij stelden voor de beslissing aan de hertog over te laten ${ }^{44}$. Alva distilleerde hierop zelf een taxatielijst en legde die op 29 oktober aan de Statenvergadering voor ${ }^{45}$.

In november stond men nog geen stap verder. De landvoogd begon met aandrang de inning der toegestane fl. 542.000.-te eisen; dat zou geschieden op de wijze zoals door een meerderheid was aangenomen. Door nogmaals een beroep te doen op het 'vervangingssysteem' hoopte hij wellicht de besprekingen weer vlot te krijgen. Hij kon de halsstarrigheid der Staten niet verkroppen; bij verder verzet - zo vervolgde hij - zou hij zich genoodzaakt zien 'alle doorlochsvolck in andere landen liggende hier in Brabant te doen comen ${ }^{46}$ ! Hij was niet van plan zijn greep op de Staten nog te lossen, zo verplichtte hij de eerste twee standen in vergadering te blijven. Ondertussen zond hij de stedelijke deputaties naar hun stadsbestuur. Op 23 november brachten zij verslag uit: Brussel en 's-Hertogenbosch hadden geen bezwaren tegen de inning der quote, Antwerpen verzette zich, te Leuven had men nog geen mening ${ }^{47}$. Maar Alva ging door. Steunend op een partiële goedkeuring, vaardigde hij op 7 december een instructie uit om de fl. 542.000.- te innen ${ }^{48}$. Het mes sneed, met de dood in het hart en wellicht hopend op een gunstige regeling waren de steden de

38. Brussel, 8 juli 1570, SAA, Pk., no 2478, los stuk.

39. 12 juli 1570 , SAL, no 1788 , los stuk.

40. Opinie van Leuven, 28 juli 1570, ibidem; Brussel, 21, 25 en 31 juli 1570, ibidem; 's-Hertogenbosch, 31 juli 1570, ibidem; Antwerpen, 31 juli 1570, ibidem.

41. Antwerpen, 2 augustus 1570, ARAB, Pap. St. Aud., no 611, fo 192-198 vo.

42. 13 augustus 1570 , ibidem, no 647 , fo 5-13.

43. Opinies van de vier Brabantse hoofdsteden, afgegeven op 20 september 1570, SAL, no 1788, losse stukken.

44. 12 en 19 oktober 1570 , ibidem, no 300, fo 298-301 vo.

45. Antwerpen, 29 oktober 1570, SAA, Pk., no 2479 , los stuk.

46. Antwerpen, 7 november 1570, ARAB, Man. Div., no 333A, fo 31-31 vo en 12 november 1570, SAL, no 300 , fo $312-312$ vo.

47. 14 november 1570, ibidem, fo 313 en 23 november 1570, ARAB, Staten van Brabant, reg. no $199^{16}$, fo $339-341$.

48. Antwerpen, 7 december 1570, SAA, Pk., no 2479, los stuk. 
volgende dag bereid Alva's eis in te willigen ${ }^{49}$. Hierop volgde een plakkaat betreffende de inning van de fl. 542.000.- ${ }^{50}$.

In deze eerste fase van de beperkingen rond Alva's tiende en twintigste penning tekenen zich enkele krachtlijnen af. De Staten vreesden permanente belastingen en wat specifiek de tiende en twintigste penning betrof waren zij van oordeel dat deze belastingen handel en nijverheid zouden ruïneren. Aanhoudend stroomden nu reeds vanuit alle steden en dorpen weeklachten toe over de achteruitgang van handel en nijverheid ${ }^{51}$. De toestand was immers ver van rooskleurig. Bij de economische stagnatie voegden zich de beginnende Opstand (beeldenstorm, plunderingen door soldaten, etc.) en plagen zoals hongersnood, pest en ongehoorde prijsstijgingen ${ }^{52}$. Opmerkelijk is ook dat herhaaldelijk in de remonstranties gewezen werd op de zware last die het inkwartieren en onderhouden van troepen voor de bevolking betekende ${ }^{53}$. Het verzet tegen de nieuwe belastingen ging vooral uit van de steden. Zij werden het meest onmiddellijk geconfronteerd met de moeilijkheden van neringdoeners en ambachtslieden. Het 'vervangingssysteem' was echter een machtig wapen in de handen van de landvoogd; de traditionele besluitvorming werd hier omgebogen in het voordeel van de machthebber. Toch kan niet worden ontkend dat het unanimiteitsbeginsel erg verlammend werkte op het politieke bedrijf. Een ander zwak punt voor de Staten waren de interne meningsverschillen over de wijze waarop men de quote zou opbrengen. Ook hier werd hel een eindeloze discussie. Alva ging er met de grove borstel door. Hij zette de Staten onder druk, dreigde met militaire sancties en stelde alles in het werk om zijn vernieuwingen door te voeren.

\section{GEEN INNING DER NIEUWE BELASTINGEN}

Sinds het akkoord van augustus waren bijna vijf maanden verlopen - men schreef reeds januari 1571 -, en nog steeds was de toegestane bede niet geïnd. Terecht schreef Viglius over de contributie van de twee miljoen gulden als over een enorm moeilijke onderneming $^{54}$. De steden bereikten geen eensgezindheid en begonnen met nog meer aandrang dan voorheen de terugtrekking der garnizoenen te eisen ${ }^{55}$. De

49. 8 december 1570 , ibidem.

50. 14 december 1570 zie: J. B. Christyn, Placcaeten ende ordonnantien van de hertoghen van Brabant, princen van dese Nederlanden, II (Brussel, 1648) 39-54.

51. Zo bijvoorbeeld klacht van Antwerpen, 5 juli 1569, SAA, Pk., no 478, los stuk en opinie der prelaten, 25 september 1571 (stuk is ongedateerd), GAsH, A. 209, fo 196.

52. J. A. van Houtte, Economische en sociale geschiedenis van de Lage Landen (Zeist-Antwerpen, 1964) 108; H. van der Wee, 'Typologie des crises et changements de structures aux Pays-Bas (XVe-XVIe siècles)', Annales. Economies. Sociétés. Civilisations, XVIII (1963) 220-224.

53. Bijvoorbeeld 's-Hertogenbosch, ongedateerd na 21 mei 1569, GAsH, A. 247, fo 461-463; 27 januari 1571 (n.s.), SAL, no 300, fo 357 vo-358; 10 december 1571, ibidem, no 301, fo 134 vo. 54. Viglius aan J. Hopperus, Brussel, 8 december 1570 in: C. P. Hoynck van Papendrecht, Analecta Belgica, I, ii (Den Haag, 1743) 604.

55. Opinies van Brussel en 's-Hertogenbosch, afgegeven op 20 januari 1571 (n.s.), SAL, no 1788, losse stukken. 


\section{G. JANSSENS}

prelaten en de edelen stelden nu voor om tijdens het eerste jaar slechts fl. 242.000.op te brengen ${ }^{56}$. Hierover bereikte men op 27 januari slechts een gedeeltelijk akkoord. Het waren opnieuw hoofdzakelijk de derde leden der steden die het been stijf hielden. Ook nu paste Alva zijn tactiek van 'vervanging' toe, vervolgens gaf hij de weigerende leden nog dertien dagen de tijd om hun mening te herzien ${ }^{57}$. Bij de bevestiging van de overeenkomst waren enkel de prelaten van 't Park, van Averbode en de abt-graaf van Gembloers bereid het stuk te ondertekenen. Uitdrukkelijk verklaarden zij dat zij hun toestemming van een eensgezinde en volledige toestemming der steden afhankelijk maakten ${ }^{58}$.

Alva was ondertussen genoodzaakt enkele toegevingen te doen. Op 22 januari werd de belasting op het dragen van goud en zilver afgeschaft ${ }^{59}$. Onder zekere voorwaarden werd aan 's-Hertogenbosch opnieuw tolvrijdom toegestaan. Het garnizoen werd er echter 'om veiligheidsredenen' behouden ${ }^{60}$. Toch konden deze concessies de stemming niet keren. De Staten bleven moeilijkheden maken. Alva's geduld werd erg op de proef gesteld.

De landvoogd vond het nu welletjes en achtte de tijd gekomen om definitief met de tiende en twintigste penning van wal te steken. Op 31 juli liet hij de Staten van alle gewesten weten dat de tiende en twintigste penning vanaf 13 augustus 1571 van kracht zouden worden ${ }^{61}$. In vergadering bijeengekomen, namen de Staten van Brabant op 11 augustus met verbazing kennis van de hertogelijke beslissing. Onmiddellijk stelden zij een rekwest op om Alva nogmaals duidelijk te maken welke schade de tiende en twintigste penning het land zouden toebrengen. Ook wezen zij de hertog op het feit dat zij reeds goed op weg waren de eerder gevraagde quote op te brengen. Tot slot verzochten zij om een audiëntie ${ }^{62}$. Na een eerste afwijzende reactie ontbood de landvoogd de Brabantse gedeputeerden tenslotte toch op 20 augustus. Hij hield hun voor dat, niettegenstaande hun remonstranties, het plakkaat der tiende en twintigste penning zonder verder uitstel zou gepubliceerd worden $^{63}$. Hij had ondertussen ook de Grote Raad van Mechelen opdracht gegeven over de toepassing van dit plakkaat te waken ${ }^{64}$.

De tiende en twintigste penning zouden dus uiteindelijk toch werkelijkheid wor-

56. Opinie van prelaten en edelen, 20 januari 1571 (n.s.), ibidem.

57. Antwerpen, 27 januari 1571 (n.s.), SAA, Pk., no 2480, los stuk.

58. 29 januari 1571 (n.s.), SAL, no 300, fo 361-361 vo.

59. Antwerpen, 22 januari 1571 (n.s.), ARAB, Staten van Brabant, reg. no $199^{16}$, fo 361-361 vo.

60. R. A. van Zuylen, Inventaris der archieven van de stad 's-Hertogenbosch, chronologisch opgemaakt en de voornaamste gebeurtenissen bevattende (Stadsrekeningen van het jaar 1399-1800), II ('s-Hertogenbosch, 1866) 844.

61. Jacobo Fitz James-Stuart duque de Berwick y de Alba, ed., Epistolario del III ${ }^{0}$ Duque de Alba don Fernando Alvarez de Toledo, II (Madrid, 1952) no 1348.

62. 11-13 en 16 augustus 1571 , SAL, no 301 , fo $39-41$ en fo 44 .

63. 20-21 augustus 1571 , ibidem, fo 47 vo.

64. Brussel, 12 augustus 1571, RAA, GAM, no 44, fo 294. 
den! Een gevoel van machteloosheid en onzekerheid overviel de Statenvergadering. Bovendien deden allerlei ontstellende geruchten de ronde. Zo vertelde men dat in Vlaanderen en in Artesië het gevreesde document reeds gepubliceerd was. De vrees was niet ongegrond: op 21 augustus verklaarde de burgemeester van Brussel opdracht te hebben gekregen het plakkaat onverwijld te publiceren en tevens commissarissen voor de inning der belastingen te benoemen. Te Leuven werd de ordonnantie op 23 augustus uitgeplakt ${ }^{65}$. Het was dus zover!

Sterker dan ooit voelden de Staten zich nu volledig in het defensief gedrongen. Meer en meer won ook de overtuiging veld dat de tiende en twintigste penning uitsluitend een initiatief van de hertog waren en dat het bevel tot daadwerkelijke heffing helemaal niet van de koning uitging ${ }^{66}$. In dit klimaat rijpte bij de Staten het plan zich rechtstreeks tot de vorst te wenden.

In september kwamen de prelaten en de stedelijke gedeputeerde te Brussel bijeen. Karel van der Linden, abt van 't Park, gaf een overzicht van de politieke toestand. Hij stelde voor om, wanneer eenmaal de toestand niet meer houdbaar zou worden, een afvaardiging naar Madrid te zenden. Terzelfdertijd spoorde hij de vergadering aan het geduld niet te verliezen ${ }^{67}$.

De Staten van Brabant bleven de afschaffing van de tiende en twintigste penning eisen. Wel waren zij bereid jaarlijks en met 'generale middelen' hun deel in de twee miljoen gulden op te brengen, en dit voor een termijn van vier jaar. Indien er echter drie maanden na dit voorstel nog geen definitieve oplossing zou gevonden zijn, zou een afvaardiging de zaak bij de koning zelf gaan bespreken ${ }^{68}$. De Staten wilden Alva onder druk zetten. Zij hoopten dat hun voorgenomen deputatie naar Philips II de hertog tot een meer redelijke politiek zou bewegen. Ook zou men hun nooit kunnen verwijten de koning niet te hebben gewaarschuwd voor mogelijke schade aan handel en nijverheid ${ }^{69}$.

Terwijl Alva vastberaden zijn wil trachtte door te zetten, lieten enkele belangrijke 'toeschouwers' hun stem horen. Begin oktober vatte Viglius in een brief aan J. Hopperus de situatie zeer inzichtelijk samen. Na de publikatie van het plakkaat, zo schreef hij, kwamen alle Nederlandse Statenvergaderingen samen om de hertog te vragen zich met de quote of met een andere bijdrage tevreden te stellen: de schade zou anders niet te overzien zijn. Nu reeds - nog vóór de uitvoering der besluiten - verlieten velen het land en kende de handel een ernstige stagnatie.

65. 18,21 en 23 augustus 1571 , SAL, no 301 , fo 47,49 vo en 50 .

66. Craeybeckx, 'De staten van Vlaanderen', 110.

67. 13 september 1571, SAL, no 301, fo 56 bis-56 bis vo. K. van der Linden (1523-1576) was de zoon van ridder Jan van der Linden, burgemeester van Leuven. Hij was abt van de Parkabdij te Heverlee van 1558 tot 1576. P. Lefèvre, 'Van der Linden (Charles)', Biographie Nationale, XXVI (Brussel, 1936) kol. 335-338.

68. 25 september 1571 , SAL, no 301 , fo 74 vo-75.

69. 26 september 1571, ibidem, fo 75 vo en SAA, Pk., no 2390, kapittel 1561-1573, no 77. 


\section{G. JANSSENS}

Viglius was verder de mening toegedaan dat het volk, 'dat het oproer schuwt en wiens stem Gods stem is', zich in deze zaak tot de koning zou wenden. Hij was immers de hoogste autoriteit ${ }^{70}$. Hopperus lichtte Philips II onmiddellijk in. Hij vreesde duidelijk oproer, niet alleen tegen de tiende penning, maar tegen heel het bestuur $^{71}$. Verschillende andere 'hoge heren' spraken hun bezorgdheid uit over Alva's financiële politiek. Reeds vroeg had kardinaal Granvelle moeilijkheden voorspeld bij een gebeurlijke inning der belastingen ${ }^{72}$. Ook Viglius en de bekende Spaanse humanist en exegeet Benito Arias Montano steunden de nieuwe belastingen niet. Speciaal wezen zij op het grote gevaar dat een eventuele emigratie zou meebrengen ${ }^{73}$. Philips van St.-Aldegonde, heer van Noircarmes, waarschuwde de koning voor 'ongelukken' wanneer men de tiende en twintigste penning zou willen ten uitvoer brengen ${ }^{74}$. Ook in Madrid waren een aantal personen de tiende en twintigste penning niet genegen ${ }^{75}$. Deze meningen waren voor Philips II erg belangrijk. Zij vormden een kritische aanvulling op de uitgebreide, plichtsbewuste, maar toch eenzijdige berichtgeving van Alva. Vooral Granvelle had nog steeds veel invloed. Hij verbleef weliswaar niet meer in de Nederlanden, maar in zijn vicaris-generaal M. Morillon had hij een uitstekende correspondent. Te Madrid waren de adviezen van Hopperus niet zonder belang ${ }^{76}$.

Alva bleef ondertussen niet werkeloos toekijken. Op 16 oktober 1571 verscheen een instructie voor de collecteurs in alle gewesten: zij dienden onverwijld aan het werk te gaan en niet te wachten op een eventuele komst van de hertog of van de koning $^{77}$. Ook bracht de landvoogd Philips II uitvoerig op de hoogte van de moeilijkheden die hij ondervond. In dit schrijven schetste de IJzeren Hertog zelf een van de meest hatelijke aspecten van zijn optreden. Hij verklaarde onder andere dat 'noch door de hoofden die hij heeft laten rollen, noch door het verkrachten van

70. Viglius aan J. Hopperus, Brussel, 2 en 15 oktober 1571 in: Hoynck van Papendrecht, Analecta Belgica, 649-651.

71. Hopperus aan Philips II, s.1., 6 oktober 1571 in: C. Piot, ed., Correspondance du cardinal de Granvelle, 1565-1583, IV (Brussel, 1884) 592.

72. Granvelle aan Gaspar Schetz, Rome, 29 april 1569 in: E. Poullet, ed., Correspondance du cardinal de Granvelle, 1565-1583, III (Brussel, 1881) 569; idem aan Karel Tisnacq, Rome 22 september 1569 in: Gachard, ed., Correspondance de Philippe II, II, 106 en idem aan G. Schetz, Rome, 24 september in: 1569 ibidem, 109.

73. Viglius aan J. Hopperus, Brussel, 23 augustus 1571 in: Hoynck van Papendrecht, Analecta Belgica, 642 en B. Arias Montano aan G. de Zayas, Antwerpen, 28 augustus 1571, in: Colección de documentos inéditos para la historia de España, XLI (Madrid, 1863) 253-254.

74. Noircarmes aan Philips II, Brussel, 5 september 1571 in: Gachard, ed., Correspondance de Philippe II, 198.

75. A. d'Ennetières, staatssecretaris van Philips II aan Viglius, Madrid 4 december 1571, ARAB, Pap. St. Aud., no 484, fo 16.

76. A. W. Lovett, 'Some Spanish Attitudes to the Netherlands (1572-1578)', Tijdschrift voor geschiedenis, LXXXV (1972) 18-19.

77. 16 oktober 1571, ARAB, Pap. St. Aud., no 611, fo 290-290 vo. 
privileges of kostuimen' hij ooit een grotere tegenstand ondervonden $\mathrm{had}^{78}$. Toch was Alva op dat ogenblik nog zeer optimistisch gestemd in verband met de mogelijke opbrengst der belastingen. Hij beschikte echter niet over de juiste bevolkingscijfers. Na correctie kon men de feitelijke opbrengst op fl. 6.000.000.- schatten. Alva verwachtte in oktober 1571 de ronde som van fl. 20.000.000. ${ }^{79}$.

De hertog moest evenwel nog enkele concessies doen. Op 21 oktober verminderde hij de belasting op de nijverheidsprodukten bestemd voor de uitvoer: men zou er nog slechts een twintigste penning dienen op te betalen ${ }^{80}$. Andere toegevingen volgden: de tiende penning op de graanverkoop werd afgeschaft; op de nijverheidsprodukten, op de produkten van de huisnijverheid, alsook op de voor de uitvoer bestemde gezouten vis was men nu nog slechts een dertigste penning verschuldigd; vloeibare stoffen, dranken en elke koopwaar die met een inhoudsmaat gemeten werd, waren van de tiende penning vrijgesteld. Ook voor geweven stoffen waren moderaties voorzien ${ }^{81}$.

Alva diende deze toegevingen natuurlijk te verantwoorden. In een brief aan de koning verklaarde hij te ervaren dat de bevolking zijn financiële politiek niet genegen was, maar anderzijds zag hij ook dat er dringend geld nodig was. De Staten bleven onverpoosd aandringen op de intrekking van de tiende en twintigste penning; om hun ter wille te zijn had hij enkele toegevingen gedaan. Volgens hem werden de steden niet gedreven door bezorgdheid voor nijverheid of visvangst, maar wel door de angst voor het feit dat zij in de toekomst hun wil aan de vorst niet meer zouden kunnen opleggen. De hertog hield het ook voor mogelijk dat de Staten zich rechtstreeks tot de koning zouden wenden; daarom spoorde hij Philips II tot onverzettelijkheid aan. Heel de brief getuigt van scherp inzicht in de toestand, maar ook van een grondig misprijzen voor de Staten en de bevolking ${ }^{82}$.

Hopperus liet een ander geluid horen. De Staten - en velen met hen - zagen in heel de financiële onderneming enkel een initiatief van de hertog, zij wilden niet geloven dat de koning er achter stond. In heel zijn optreden toonde de hertog zich bovendien zeer onverzettelijk: hij wilde geen afvaardiging ontvangen, nog minder wilde hij een deputatie naar de koning laten vertrekken. Een andere moeilijkheid noemde Hopperus het feit dat alle Staten eensgezind en onafhankelijk van elkaar, de tiende en twintigste penning een catastrofe voor het land noemden ${ }^{83}$.

Alva bleef de inning van de tiende en twintigste penning eisen, hij had naar zijn gevoel wellicht al genoeg toegegeven ${ }^{84}$. Toch gebeurde er niets, en het volk keek

78. Alva aan Philips II, Brussel, 19 oktober 1571 in: Duque de Alba, ed., Epistolario, no 1452.

79. Craeybeckx, 'Alva's tiende penning', 32-35.

80. SAA, Pk., no 2766 , fo 152 vo- 153 vo.

81. Brussel, 2 november 1571, ARAB, Pap. St. Aud., no 611, fo 295-297.

82. Alva aan Philips II, Brussel, 4 november 1571 in: Duque de Alba, ed., Epistolario, no 1471.

83. J. Hopperus aan Philips II, Madrid 8 november 1571 in: Gachard, ed., Correspondance de Philippe II, 210.

84. Brussel, 30 november 1571, ARAB, Pap. St. Aud., no 611, fo 305, 307, 309, 310. 


\section{G. JANSSENS}

met verlangen uit naar een nieuwe landvoogd waarvan men een welwillender en vooral redelijker beleid verhoopte ${ }^{85}$.

In een schrijven van 23 december 1571 zette Alva nogmaals zijn visie op de belastingen uiteen. De prelaten en de edelen hadden op 27 januari toegestemd in een jaarlijkse bede van fl. 242.000.-, de eerste twee leden van Brussel, Antwerpen en 's-Hertogenbosch hadden zich daarbij aangesloten. Voor de hertog betekende dit dat de bede aanvaard was: hij had immers een meerderheid achter zich. Ook meende hij dat er van nieuwe belastingen geen sprake was, enkel de vorm was veranderd $^{86}$. De prelaten, de edelen, alsook de eerste twee leden van de boven vermelde drie hoofdsteden waren het met deze visie eens ${ }^{87}$. Tegelijkertijd stelde de hertog alles in het werk om op het platteland en in de kleinere steden de collectatie van de tiende en twintigste penning te doen starten. Hij schreef naar de stadsbesturen en liet overal 'visitaties' houden, zonder resultaat evenwel ${ }^{88}$.

\section{FAILLIET VAN DE FINANCIËLE POLITIEK}

In de steden begon eind 1571 duidelijk iets te roeren. Te Antwerpen was men bevreesd dat sommige reeds met imposten of accijnzen belaste produkten als bier en wijn nu ook door de tiende penning zouden getroffen worden ${ }^{89}$. De brouwers vreesden dat én de brouwers-producenten én de tappers de tiende penning zouden moeten betalen. Samen met een brief zond het stadsbestuur een rekwest van de brouwers naar de gedeputeerden te $\mathrm{Brussel}^{90}$. Op 15 december maakte het Antwerpse stadsbestuur ook melding van een rekwest van de vissers ${ }^{91}$. Te Leuven waren er moeilijkheden met de vleeshouwers. Zij stuurden een afvaardiging naar de Statenvergadering en namen contact op met hun Brusselse collega's ${ }^{92}$. Te 's-Hertogenbosch waren er klachten vanwege de visverkopers, de vleeshouwers en de bakkers ${ }^{93}$.

Te Brussel was de toestand zo gespannen dat het er tot een staking van ambachts-

85. Viglius aan J. Hopperus, Brussel, 3 november 1571 in: Hoynck van Papendrecht, Analecta Belgica, 653. Men verwachtte don Juan de la Cerda, hertog van Medina-Celi. Reeds op 25 september 1571 benoemd, arriveerde hij pas in juni 1572 zie: M. Baelde, De collaterale raden onder Karel Ven Filips 11(1531-1578). Bijdrage tot de geschiedenis van de centrale instellingen in de zestiende eeuw (Brussel, 1965) 246-247.

86. Christyn, Placcaeten, III (Brussel, 1664) 382-383.

87. 23 december 1571 , SAL, no 301 , fo 159 vo.

88. ARAB, Pap. St. Aud., no 610, fo 34-376. Over de toestand zie: Contador Juan de Isuenca aan kardinaal de Espinosa, Brussel, 24 december 1571, BM, Add., no 28. 387, fo 56.

89. Antwerps stadsbestuur aan Antwerpse deputatie te Brussel, Antwerpen, 3 december 1571, SAA, Pk., no 2408, los stuk.

90. Antwerps stadsbestuur aan Antwerpse deputatie te Brussel, Antwerpen, 5 december 1571, ibidem.

91. Antwerps stadsbestuur aan Antwerpse deputatie te Brussel, Antwerpen, 15 december 1571, ibidem.

92. 14 en 15 december 1571, SAL, no 301, fo 141 en 142 vo.

93. Van Zuylen, Inventaris 's-Hertogenbosch, 859-860. 
lieden en neringdoeners $\mathrm{kwam}^{94}$. Van 8 tot 12 december werd er in de vleeshalle niets verkocht ${ }^{95}$. Het stadsbestuur begreep de klachten der ambachtslieden en gaf hun de raad een rekwest met grieven aan de hertog te overhandigen. Zij zouden er duidelijk dienen in te vermelden dat zij de tiende penning niet uit weerspannigheid afwezen, maar wel wegens hun grote materiële nood ${ }^{96}$. Op 8 januari 1572 gingen te Brussel alle winkels dicht ${ }^{97}$. Er werd geen verse vis verkocht, wollen of zijden stoffen waren niet te verkrijgen, de brouwers legden het werk neer en ook de vettewariërs, de kruideniers en de apothekers hielden hun deuren gesloten. Van hogerhand werden speciaal de brouwers aangemaand het werk te hervatten: er werd gedreigd met een boete van fl. 100.-, met verbeurdverklaring van goederen en zelfs met de doodstraf! Ook dreigde Alva in de huizen waar de winkels gesloten bleven Spaanse soldaten in te kwartieren, of op zijn minst een sterke troepenmacht in het stadscentrum samen te trekken. Zelfs het van huis tot huis trekken der collecteurs leverde niets op $^{98}$ ! In de ogen van de hertog waren de Brusselse wethouders de schuld van alles: zij hadden immers véél strenger dienen op te treden. Hij liet hun weten dat indien zij tegen de brouwers geen maatregelen namen, dit hun duur te staan zou komen ${ }^{99}$. Het stadsbestuur wilde bemiddelend optreden en stelde daarom voor zelf de tiende penning te betalen. Noch Alva, noch de brouwers konden zich met dat voorstel verzoenen ${ }^{100}$. Op 13 februari gingen de winkels opnieuw open. Daar de hertog aan de tiende penning bleef vasthouden, legden de vleeshouwers op 15 maart opnieuw het werk neer ${ }^{101}$.

Alva nam bij deze gebeurtenissen zijn toevlucht tot afschrikwekkende dreigementen. Er werd zelfs gezegd dat hij van plan was enkele van de meest vooraanstaande Brusselaars (de dekens van de ambachten?) aan hun deurpost te laten opknopen. Het nieuws van de inname van Den Briel zou deze bloedige repressie hebben verhinderd. Hoewel dit verhaal als legende dient bestempeld te worden, is het toch illustratief voor de toenmalige atmosfeer ${ }^{102}$.

De Staten van Brabant hadden ondertussen hun tijd niet verloren. Vooral vanaf januari 1572 begonnen de voorbereidingen voor een deputatie naar de koning

94. Hierover A. Wauters, La levée du dixième denier (Episode de l'histoire de Bruxelles) (Brussel, 1841). Belangrijk is eveneens R. C. Bakhuizen van den Brink, 'Over den tienden penning', Cartons voor de geschiedenis van den Nederlandschen vrijheidsoorlog, I (3e dr.; Den Haag, 1891) 186-289. De auteur publiceert en bespreekt een anoniem gedicht dat de periode 8 januari-2 april 1572 behandelt. Het berust te Brussel, ARAB, Man. Div., no 393 bis, fo 122-123. De uitgave is echter nogal onnauwkeurig.

95. SAL.no 301, fo 137.

96. 21 december 1571, SAB, no 1724 , fo 185 vo-186.

97. ARAB, Man. Div., no 393 bis, fo 122 .

98. 14-15 januari 1572 (n.s.), SAL, no 301 , fo 171 vo-172 vo.

99. 19 januari 1572 (n.s.), ibidem, fo 178.

100. 6 februari 1572 (n.s.), ibidem, fo 195.

101. ARAB, Man. Div., no 393 bis, fo 122 vo.

102. Craeybeckx, 'De tiende penning van Alva', 195-196. 


\section{G. JANSSENS}

vaste vorm te krijgen. Er werd gewerkt aan de samenstelling van een dossier en men keek uit naar geschikte personen om de reis te ondernemen. Vooral dit laatste was geen gemakkelijke opgave. Tenslotte stonden abt Karel van der Linden, abtgraaf Lambert Hancaert van Gembloers, Lodewijk van der Linden (broer van Karel en schepen van Leuven), dr. jur. Bartholomeus Kieffel en griffier Cornelius Weellemans klaar om te vertrekken ${ }^{103}$. Niettemin bleef Alva heviger dan ooit de inning der tiende en twintigste penning eisen ${ }^{104}$. Had hij immers niet gezworen de Nederlanden niet te zullen verlaten vooraleer hij deze belastingen zou hebben geind $^{105}$ ? Toch kon de deputatie vertrekken. Niet zonder moeite bereikte men de Spaanse hoofdstad. Daar werd samen met de vertegenwoordigers van andere Nederlandse gewesten de afschaffing van de nieuwe belastingen gevraagd. De afgevaardigden werden er niet onvriendelijk ontvangen en uiteindelijk werd het doel bereikt. Op 26 juni 1572 verving Philips II de tiende en twintigste penning door een jaarlijkse bede van twee miljoen gulden ${ }^{106}$. De financiële problemen waren niet uit de weg geruimd, maar het onmiddellijk dreigend gevaar voor handel en nijverheid was afgewend. De politieke toestand in de Nederlanden was er ondertussen niet klaarder op geworden: de 'rebellen' behaalden nieuwe successen, de inname van Den Briel werd een symbool en van 19 tot 22 juli was te Dordrecht de 'Eerste Vrije Statenvergadering' van de Staten van Holland bijeengekomen ${ }^{107}$. Van nu af zou Alva's aanwezigheid in de Nederlanden vooral van militaire aard zijn.

Alva's financiële politiek was op een mislukking uitgelopen. Lange tijd had hij handig kunnen manoeuvreren door het herhaald aanwenden van de 'vervanging' der weigerende minderheden. Uiteindelijk strandde zijn politiek op de onwil van de bevolking ook maar iets te betalen. Het verzet kwam speciaal scherp tot uiting in de steden. De Brusselse staking van 1572/1573 is hiervan een treffend voorbeeld. Wel mogen we niet uit het oog verliezen dat vooral de ambachtslieden en neringdoeners hierbij de drijvende kracht waren. De Staten werden duidelijk gedreven door een grote bezorgdheid voor de sociaal-economische welvaart van het land. Hierbij voegde zich nog het onbehagen, veroorzaakt door het feit dat de belastingen bedoeld waren om de Spaanse oorlogsinspanningen in de Nederlanden te financieren.

103. 8 maart 1572 (n.s.), zie: Gachard, ed., 'Relation du voyage', 254-263.

104. Brussel, 5 maart 1572 (n.s.), SAA, Pk., no 2480, los stuk.

105. M. Morillon aan Granvelle, s.1., 3 maart 1572, zie: Piot, ed., Correspondance Granvelle, 120.

106. Gachard, ed., 'Relation du voyage', 359-361. De Brabantse deputatie naar Spanje behandelden we uitgebreider in onze onuitgegeven licentiaatsverhandeling 'De staten van Brabant en Alva's financiële politiek. Het verzet tegen de Xe en XXe penning (1569-1572)' (Leuven, 1971) en in het artikel 'Gezantschap naar Filips II', Spiegel Historiael, VIII (1973) 82-87.

107. H. A. Enno van Gelder, 'De strijd in Holland en Zeeland, 1572-1576', Algemene Geschiedenis der Nederlanden, V (Utrecht-Antwerpen, 1952) 41-48. Over de Hollandse Statenbijeenkomst, J. J. Woltjer, 'Inleiding', Opstand en onafhankelijkheid. Eerste vrije statenvergadering Dordrecht 1572. Catalogus (Dordrecht, 1972) 5-28. 
Het in een periode van laagconjunctuur zuur verdiende geld zou dus afvloeien naar de 'roversbenden' die stad en dorp onveilig maakten. In feite een hopeloze situatie, want juist door het feit dat zij niet betaald werden sloegen de huursoldaten aan het plunderen. Het verzet binnen de Statenvergadering was lange tijd niet erg duidelijk en zeker niet algemeen. Er werd geen unanimiteit bereikt, maar door de 'vervanging' kon de landvoogd dit obstakel negeren. Pas met de deputatie naar Spanje kwam er schot in de zaak. De deputatie heeft ongetwijfeld sterk bijgedragen tot de uiteindelijke intrekkingen der belastingen. Toch menen we dat de stemming rond de penningen en vooral het niet op gang komen van de daadwerkelijke inning eveneens zeer belangrijke factoren in het verzet zijn geweest.

Het verzet tegen de tiende en twintigste penning is slechts één aspect van de moeilijkheden veroorzaakt door een steeds verder doorgevoerde centralisatie van het bestuur. In het kader van een meer en meer absolutistisch en centraal geleid wereldrijk was de macht der lokale Statenvergaderingen een ernstige hinderpaal. Nieuwe zware belastingen zijn steeds impopulair; wanneer zij bovendien uitgevaardigd worden ten tijde van politieke en economische moeilijkheden kunnen zij des te meer mede de oorzaak zijn van ontevredenheid en opstand ${ }^{108}$.

108. Gaarne danken wij professor J. A. van Houtte voor zijn waardevolle raadgevingen en bemerkingen die wij bij het schrijven van dit artikel van hem mochten ontvangen. 


\title{
Beschouwingen over de staatsrechtelijke toekomst van Nederlandsch-Indië
}

\author{
INGELEID DOOR J. ERKELENS
}

\section{TER ORIËNTATIE}

Dit stuk, waaraan titel, datum en ondertekening ontbreken, is afkomstig uit het archief van het voormalig ministerie van koloniën, waarvan de bescheiden over de jaren na 1900 thans onder beheer zijn van het ministerie van binnenlandse zaken, Leeghwaterstraat 125 te 's-Gravenhage. Uit een aantekening op de omslag ervan blijkt, dat het op 30 juli 1938 door J. F. W. van der Meulen is overgedragen aan het kabinet van de minister van koloniën en dat het door mr. K. F. Creutzberg werd geschreven. Van der Meulen was een goede vriend van Creutzberg en diens opvolger als directeur van het departement van onderwijs en eredienst in Nederlands-Indië in 1922.

Deze verhandeling is eerst onlangs weer te voorschijn gekomen, toen een zogenaamd 'tussen-archief' werd geordend; een archiefje, dat bij de opheffing van het ministerie van zaken overzee (de laatste officiële benaming voor het ministerie van koloniën) in 1959 werd gevormd door bescheiden waarvan de bestemming toen niet meer duidelijk was. Mr. P. Creutzberg (Creutzbergs oudste zoon) zei mij, dat deze beschouwingen hem onbekend waren en evenmin bij anderen bekend zijn. Vermoedelijk heeft Van der Meulen het uit overwegingen van piëteit onder zich gehouden. Of Creutzberg het stuk heeft opgesteld om het op enigerlei wijze te publiceren, is niet bekend. Hij moet het hebben geschreven na januari 1933 en voor 22 oktober van dat jaar, de datum van zijn overlijden ${ }^{1}$.

Karel Frederik Creutzberg werd geboren op 18 december 1879 te Woudenberg. $\mathrm{Na}$ zijn gymnasiumtijd in Kampen studeerde hij rechten te Utrecht (1897-1902), waar hij op 19 januari 1904 cum laude promoveerde tot doctor juris op het proefschrift Misdrijf en Overtreding. Een ambtelijk rapport, opgesteld naar aanleiding van zijn sollicitatie voor de Indische dienst, leverde op dit werk het volgende commentaar:

Het getuigt van aanleg - of voorkeur - voor philosophische subtiliteit, doch ook van practisch-critischen geest en van bekwaamheid om omvangrijke stof te verwerken ${ }^{2}$.

1. Zie p. 38, noot**.

2. 's-Gravenhage, Archief van het ministerie van koloniën, verbaal 2 maart 1904, no. 2. 